\title{
MORALIDADES DA DEFESA PÚBLICA: ASSISTIR E "PROCEDIMENTALIZAR"?
}

\author{
MORALITIES OF PUBLIC DEFENSE: ASSIST AND \\ "PROCEDIMENTALIZE"?
}

\author{
Marilha Gabriela Reverendo Garau ${ }^{l}$ \\ Michelle Nascimento Babo ${ }^{2}$
}

\begin{abstract}
RESUMO
O presente trabalho tem por objetivo compreender em que medida as práticas profissionais dos defensores públicos atuantes em Varas Criminais de dois municípios da Baixada Fluminense, no Rio de Janeiro, são direcionadas pelas moralidades desses atores. Nesse sentido, o trabalho busca descrever práticas e discursos informadores observados na atuação de defensores públicos nas audiências das Varas Criminais bem como na condução da atividade defensiva como um todo. Nesse exercício, identifica-se de que forma essas práticas conduzem e impactam a relação desses profissionais com os indivíduos que utilizam o serviço da Defensoria Pública. A pesquisa parte da metodologia proposta pela Antropologia do Direito, a etnografia, com base empírica, construída a partir da observação direta (Malinowski, 1978) e participante (Becker, 1993). Neste exercício são conjugadas a análise entre discursos e práticas dos defensores públicos orientadas pela descrição densa (Geertz, 2008) do fenômeno jurídico-social.
\end{abstract}

\section{PALAVRAS-CHAVE:}

Moralidades; Baixada Fluminense; Justiça Criminal; Defensoria Pública

\footnotetext{
1 Doutora em Ciências Jurídicas e Sociais pelo Programa de Pós Graduação em Sociologia e Direito da Universidade Federal Fluminense. Mestre em Direito Constitucional pelo Programa de Pós Graduação em Direito Constitucional pela Universidade Federal Fluminense. Mestre em Direito Penal e Política Criminal pela Universidade de Málaga na Espanha. Professora colaboradora do Curso de Bacharelado em Segurança Pública e Social/UFF. Foi Professora substituta de Direito Penal e Direito Processual Penal Direito/UFRRJ. Advogada. Foi Presidente da Comissão de Direito Eleitoral e Reforma Política da OAB Niterói. Integrante da Comissão de Políticas Públicas sobre Drogas da OAB/RJ. Professora contratada na Graduação de Direito na Modalidade Parceladas na UNEMAT (Universidade Estadual do Mato Grosso) e na Pós-Graduação em Direito da UNESA (Universidade Estácio de Sá). Pesquisadora associada ao Instituto de Estudos Comparados em Administração Institucional de Conflitos (INCT-inEAC) e ao Laboratório de Estudos sobre Conflito, Cidadania e Segurança Pública (Laesp). marilha_garau@hotmail.com.

${ }^{2}$ Graduada em Direito pela Universidade Federal Rural do Rio de Janeiro / Instituto Multidisciplinar (UFRRJ/IM) especialista em Criminologia e Segurança Pública pela Universidade Iguaçu (UNIG) e mestranda do Programa de Pós-Graduação em Justiça e Segurança da Universidade Federal Fluminense (PPGJS/UFF). michellebabo@gmail.com
} 


\begin{abstract}
This paper aims to understand to what extent the professional practices of public defenders of the Criminal Courts of two municipalities in the Baixada Fluminense, in Rio de Janeiro, are guided by the moralities of these actors. In this sense, the work seeks to describe practices and information discourses observed in the performance of public defenders in the hearings of the Criminal Courts, as well as in the conduct of defensive activity too. In this exercise, we identify how these practices lead and impact the relationship of these professionals with individuals who use the service of the Public Defender. The research starts from the methodology proposed by the Anthropology of Law, ethnography, with an empirical basis, built from direct observation (Malinowski, 1978) and participant (Becker, 1993). In this exercise, it is identified how these practices lead and impact the relationship of these professionals with individuals who use the service of the Public Defender's Office. The research starts from the methodology proposed by the Anthropology of Law, ethnography, with an empirical basis, built from direct observation (Malinowski, 1978) and participant (Becker, 1993). In this exercise, the analysis between the speeches and practices of public defenders is combined, guided by the dense description (Geertz, 2008) of the legal-social phenomenon.
\end{abstract}

\title{
KEYWORDS:
}

Moralities; Baixada Fluminense; Criminal Justice; Public Defender

\section{INTRODUÇÃO}

Por força da Lei Complementar 80/1994 a Defensoria Pública é uma instituição permanente, essencial à função jurisdicional do Estado, tendo como funções prioritárias a orientação jurídica, a promoção dos direitos humanos e a defesa dos direitos individuais $e$ coletivos, judicial e extrajudicialmente em todos as esferas e áreas. A instituição se apresenta ${ }^{3}$ como um instrumento de inclusão democrática já que sua função institucional visa oferecer, de forma integral e gratuita, assistência e orientação jurídica aos cidadãos que não possuem condições financeiras de pagar as despesas destes serviços, defendendo os interesses da cidadania.

Tendo os mandamentos legais e constitucionais como norte informativo no que se refere à atuação da Defensoria Pública, muitos estudantes de Direito optam, ainda na universidade, pela carreira pública. A ideia de que ser defensor público é escolher o "lado bom da força" está

\footnotetext{
${ }^{3}$ http://www.defensoria.rj.def.br/Institucional/o-que-e-defensoria. Acesso em 29/07/2019.
} 
difundida entre os profissionais. A escolha pela instituição muitas vezes é atrelada à uma noção de "proteção dos mais fracos ante as arbitrariedades do Estado", fato que dissemina e reitera uma postura de tutela em relação aos assistidos, em detrimento de uma possibilidade de orientação emancipadora, inclusive no que se refere à educação sobre direitos para a cidadania (Garau e Luz, 2017).

Os defensores públicos mais apaixonados explicam que não poderiam atuar em outras instituições, já que não têm estômago para negar remédios a doentes terminais no âmbito das ações da Fazenda Pública, como fazem os profissionais que atuam na procuradoria; ou apresentar uma denúncia e pedir a prisão preventiva quando uma mãe furtou uma lata de leite para alimentar um filho faminto, em alusão à forma como atuam seus antagonistas diretos na esfera criminal, os promotores de justiça.

Tendo como norte os discursos desses profissionais, o presente trabalho propõe explicitar e compreender as práticas de defensores públicos que atuam em dois municípios da Baixada Fluminense no Rio de Janeiro. Nesse sentido, o presente trabalho busca descrever práticas e discursos informadores presentes na atuação de defensores públicos em audiências de Vara Criminal em suas interações com outros atores vinculados ao Estado, bem como no que se refere à relação com aqueles indivíduos que utilizam o serviço da Defensoria Pública. O objetivo é discutir de que modo esses atores produzem seus próprios significados sobre a atuação no âmbito do processo judicial e da relação com os cidadãos que recorrem ao serviço por eles prestado.

A pesquisa foi conduzida a partir de dois campos distintos e complementares. A primeira autora constrói sua interação com os interlocutores a partir da observação direta de audiências criminais e entrevistas com os atores da Defensoria Pública no Município I, no campo que consolidou seu trabalho de campo da pesquisa de doutorado. Por sua vez, a segunda autora atuou na instituição na condição de estagiária durante um ano, na Defensoria Pública do Município II, numa Vara Criminal que conjugava também as atividades do Juizado de Violência Doméstica e Familiar Contra a Mulher e Juizado Especial Criminal, sendo uma observadora participante.

Portanto, a investigação é construída a partir da observação direta (Malinowski, 1978) e participante (Becker, 1993). Neste exercício são conjugadas a análise entre discursos e 
práticas dos defensores públicos, e da descrição densa (Geertz, 2008). A opção por não identificar os municípios está amparada por uma premissa ética, que visa preservar os profissionais entrevistados. Assim, será apresentado um estudo empírico e suas respectivas reflexões no que se refere aos discursos e práticas de atores vinculados ao judiciário brasileiro. O foco está no procedimento e nos rituais desses atores enquanto representantes de um serviço público estatal.

\section{A DEFENSORIA PÚBLICA EM AÇÃO: A AUDIÊNCIA CRIMINAL}

O defensor chegou apressado. Ele estava duas salas adiante no corredor da sala onde estávamos. Acumulava, além da vara criminal pela qual era responsável, a vara onde aconteceria audiência, de titularidade de outra defensora pública que estava de férias. O juiz também não era o titular daquela vara. Assim como o defensor, ele acumulava aquela onde aconteceria a audiência com a vara criminal da qual era titular.

Momentos atrás, enquanto aguardavam a defesa, juiz e promotor conversavam amigavelmente sobre as férias do acusador que retornara há poucos dias da Europa, mas se queixava de ter voltado tão depressa ao trabalho; o viajante também reclamava do calor e da lotação das cidades no mês de junho. O juiz aquiesceu e declarou sobre sua preferência em viajar no início do ano, quando as temperaturas são baixas e as ruas estão mais desertas. Mas, para ele, o velho continente já não tinha mais o mesmo glamour de anos atrás. A decadência foi relacionada à enorme quantidade de turistas brasileiros que agora visitavam os países recentemente e à imensa quantidade de imigrantes recebidos pela União Europeia nos últimos anos. "Paris está decadente", sentenciou.

Um pouco afobado, o defensor cumprimentou amigavelmente os dois que já compunham a cena. Tomou assento e pediu para ver os autos processo do caso. Eles já se conheciam. Também conheciam a defensora que estava de férias. Todos se tratavam por seus nomes. Nas comarcas do interior, a noção de que todos são uma família judicial (Nuñez, 2018, p. 80) é mais evidente. O número reduzido de varas e, consequentemente, dos profissionais vinculados a elas possibilita que a relação de proximidade entre os atores seja mais intensa. 
O defensor folheava os autos em um descompasso apressado. Sob o foco de minha atenção e dos demais outros atores daquela cena, percebi que sua respiração ainda era acelerada, mas que aos poucos ia se normalizando entre a caça à página da denúncia e suas anotações no pequeno bloco de notas que levava consigo. Ele explicou ao juiz que ainda não tivera um primeiro contato com o acusado porque o réu não estava na carceragem $^{4}$ quando ele se reunira com os outros presos que também estavam lá naquele dia. Diariamente presos aguardando julgamento são levados do presídio de origem à Comarca onde será realizada a audiência. Muitos estão acautelados em Japeri, Bangu, Benfica e até em São Gonçalo. Não raramente esses presos não chegam no horário agendado das audiências, já que é necessário atravessar a cidade até o fórum de destino e cada carro do órgão responsável pelo transporte leva mais de um preso que precisam comparecer a comarcas diferentes.

Uma mulher, que observava a tudo em silêncio enquanto mexia no computador, atendeu ao pedido do juiz e ligou para a carceragem. Depois de alguns instantes aguardando na linha confirmou a chegada do preso. "Posso mandar trazer"? O juiz aquiesceu e anunciou que o defensor poderia conversar com o acusado ali mesmo, na sala de audiências. "Hoje estamos com tempo". O juiz se levantou e sugeriu uma pequena pausa, convidando o promotor para um café.

Ficamos por longos minutos na sala. Eu, a mulher que voltara a olhar para a tela do computador e o defensor público que permanecia sentado à esquerda da mesa de audiências e continuava a folhear o processo de um lado a outro, vez em outra mexendo no celular. Eu pensava sobre o nó perfeito de sua gravata azul. Seu terno cinza contrastava com o negro dos outros dois homens que até pouco tempo também compunham a cena. Ele tinha trinta e um anos. Era defensor público "por paixão". Cursou direito em uma instituição privada e tinha seis anos de defensoria pública, dois anos no crime. Nos quatro anos que antecederam a experiência

\footnotetext{
${ }^{4}$ Carceragem é o local para o qual são direcionados aqueles que aguardam julgamento presos. Quando são levados do presídio para as audiências do processo são direcionados a este espaço até serem convocados pelo juiz para estar presente no ato. No Município I a carceragem fica no subsolo fórum, dividindo espaço com uma parte do estacionamento e só pode ser acessada através de um único elevador lateral. Apenas advogados, defensores, juízes e promotores podem ter contato com os presos na carceragem. As instalações remontam uma prisão. A entrada do local remete à um presídio propriamente dito. Há detectores de metal e os advogados precisam deixar celulares e outros pertences em um armário antes de ir às salas reservadas para conversar com os presos. $\mathrm{O}$ espaço onde os presos conversam com seus advogados lembra bastante o cenário dos filmes americanos. Um corredor com seis portas do lado esquerdo. Dentro da porta uma divisória de vidro e um telefone. No caso do Município II a estrutura da carceragem é semelhante, porém, de menor proporção; havia apenas uma sala denominada "parlatório", no subsolo do fórum, para que os advogados ou representantes da defensoria se comunicassem com os presos através de um interfone tendo uma vidraça como anteparo. Da mesma maneira, se assemelha às instalações de uma prisão.
} 
criminal trabalhou no cível. Segundo ele os inventários eram mais trabalhosos, "O cara que tá preso não tem ninguém atrás do dinheiro dele, agora quando morre, vou te contar...", costumava brincar. Ele me contou que passou parte de sua infância em Nova Iguaçu, na Baixada Fluminense, mas que, embora já não vivesse na baixada há muitos anos, conhecia as condições de pobreza da região e que por isso, sempre ficou muito satisfeito por estar lotado ali e poder desenvolver seu trabalho institucional na região.

O réu chegou. Ele estava algemado com as mãos na frente do corpo. Um policial alto e robusto lhe conduziu até a seu lugar cativo na sala de audiência: a ponta da mesa. O rapaz negro e franzino não aparentava mais de dezoito anos de idade. O policial ordenou que o rapaz sentasse e colocasse a mão embaixo da mesa, "não coloca em cima!". Imaginei que o condutor fosse se retirar, mas ele ficou lá de pé, ao lado do acusado.

"Devo sair?", perguntei reticente para o defensor que afrouxava sua gravata. Provavelmente eu estava mais incomodada com a presença do policial e da mulher que não desgrudava os olhos do computador do que com a minha própria condição de observadora. "Não precisa, vai ser jogo rápido". Voltei minha atenção para a conversa entre o advogado público e o acusado. Não precisei fazer muito esforço para ouvir. Conversavam em tom normal, inobstante o fato de não estarem a sós. Eles não se conheciam. Nunca antes haviam se visto.

O defensor se apresentou dizendo que era o responsável pela defesa do caso naquele dia. A acusação era de tráfico de drogas. "Você tá pensando em confessar?", o acusado pareceu confuso. Adiantou-se em explicar que era usuário de crack. Disse que fazia uso da substância desde os doze anos de idade e que já fora submetido a um tratamento, mas que não conseguia parar pois aquela era a sua doença. O português dele me soava ruim. Trocava algumas letras e dava ênfase ao final de todas as vogais. Também não usava muito o plural. Ele gaguejava muito. Parecia estar com medo.

- Entendi, mas você tá sendo acusado de tráfico. Você pode me contar melhor o que aconteceu no dia que você foi preso pra eu poder fazer uma defesa melhor pra você? - Eu tavo lá na crocolândia, perto do beco, doidão já. Tinha usado muita droga. Mais de cem pessoa tudo lá na fila pra comprar as droga. Aí a polícia já chegou atirano. Geral correu, eu não conseguia nem levantar. Fiquei sentado no chão. Eles já chegaram esculachando dizendo que a droga era minha. Deita no chão. Que não sei o que lá. Aí depois quando eu contornei eu tavo no carro deles lá. Aí pra delegacia eles falaram que eu tava com um quilo de droga. Mas eu não tavo.

(Notas do caderno de campo) 
O Réu levantou as mãos algemadas com certa dificuldade. Eu não pude ver porque ele estava de costas para mim. Depois de ouvir sua narrativa, imaginei uma mão retorcida. Mas, ainda assim, não pude vê-la. Ele relatou que tinha esmagado a mão debaixo de um carro no dia em que dormia na rua. Estava drogado naquele dia. Ele completou explicando que esteve no hospital dois dias antes da ação policial que resultou em sua prisão. "Eu tavo passano fome porque num podia carregá um $1 \mathrm{~kg}$ de arroz pra comer, como que ia carregar um quilo de droga?!".

A versão do acusado não pareceu afetar o defensor. Foi como se o réu não tivesse dito nada. Não parecia surpreso com o relato. Perguntou ao homem se ele já tinha sido processado antes. Sim e não. O homem nunca fora condenado, mas quando adolescente foi levado à delegacia por um ato infracional, mas não foi fichado. O defensor voltou sua atenção para os autos novamente. Confirmou a versão do réu. Ele não tinha antecedentes criminais. O defensor anotou a página da folha de antecedentes criminais (FAC) em seu caderninho e prosseguiu:

- Você trabalha?

- Eu tô desempregado desde 2015, mas antes eu era ajudante de pedreiro. Depois com as drogas nem consegui voltar mais.

(Notas do caderno de campo)

O defensor coçou a cabeça e voltou a folhear os autos. Anotou as duas últimas informações em um bloco de notas.

- Ok. Quer me perguntar alguma coisa?

- É pra eu falar o que, doutor? Eu posso falar com o juiz? Dirigir a palavra a ele? Explicar o que aconteceu?

- Você só deve falar com o juiz se ele falar pra você, mas no seu caso... olha, sinceramente, eu acho melhor você não falar nada.

- Mas eu não queria não falar não, doutor. Todo mundo que tá lá em Bangu fica preso porque não quis falar. Aí que o juiz mete o pau mesmo.

- Mas não tem necessidade de você falar. Eu vou fazer a sua defesa e explicar tudo isso que você tá me dizendo. Não tem nada na lei que diga que você falar ou não falar vai causar a sua condenação. Eu acho melhor você ficar calado, até porque nada do que você diga vai ter mais relevância do que o que os policiais vão dizer. Então por isso, pra evitar que você se enrole, de repente com uma das perguntas do promotor, é melhor você exercer o seu direito constitucional ao silêncio. É direito seu, não se preocupa que o juiz não pode usar isso contra você.

(Notas do caderno de campo)

O réu pareceu confuso e até um pouco desapontado. Permaneceu cabisbaixo durante toda a audiência. Escutou as testemunhas de acusação em silêncio e assim permaneceu até o final. Sua versão sobre os fatos não foi exposta oralmente pela defesa. "Ele vai se valer do direito ao silêncio, Excelência”. 
A defesa também não expos a narrativa do acusado nas alegações finais. O defensor costumava dizer que não se pode "inventar muito" pois, segundo ele, versões muito detalhadas são facilmente rechaçadas pela acusação e desconsideradas no momento da sentença. Em outros casos ele também pedia para os réus ficarem calados exercendo o direito constitucional ao silêncio. Segundo ele a defensoria pública fica de "mãos atadas" porque não dispõe de meios de produzir provas. E versões sem provas são inúteis e "interpretadas como tentativas desesperadas" não só pela acusação e pelos julgadores, mas também por ele mesmo, já que se sentia envergonhado quando advogados particulares tentavam emplacar versões defensivas. " $A$ gente precisa entender que o réu é o fodido, a situação dele é essa. O Estado tem todas as provas contra ele, a gente pode tentar amenizar a condenação, diminuir as penas, mas sinceramente, absolvição é quase impossível".

Nesse sentido é possível identificar uma valoração de quem o indivíduo é dentro da sociedade, já que sua condição enquanto ser social trabalhador e ter ou não antecedente criminal são pontos mais significantes para promoção da defesa do que os fatos dos quais é acusado.

Espera-se, portanto, que a aparência e o comportamento dos presos sejam compatíveis, de modo que as características visíveis relacionadas a determinado estereótipo sejam reforçadas pelas características não visíveis - trabalho, local onde moram, escolaridade, antecedentes e afins. Por essa razão, os argumentos mais mobilizados pela defesa são focados em desconstruir o estigma da figura criminosa (Goffman, 1985) e dar lugar a uma noção de cidadania regulada (Cardoso, 2019, p. 201). Tal cidadania está expressa na carteira de trabalho, já que profissões classificadas como "bicos" e trabalhos no setor informal da economia não são considerados potenciais para embasar a desconstrução de tal imagética.

Dentro da estrutura do judiciário o réu ocupa um lugar bastante frágil. E, apesar dos dizeres constitucionais de que o réu tem direito de produzir sua autodefesa, ou seja, falar sobre o fato que aconteceu em juízo, sua voz é silenciada, seja explicitamente, como no caso mencionado ou simbolicamente, já que as versões dos fatos explicitadas pelos réus são desconsideradas.

A condição de descrédito está posta e previamente determinada no papel social representado e reconhecido por todos. Inclusive ele está "marcado" por um signo que presume sua condição de criminoso e define seu lugar na sociedade. Para além disso, as regras do jogo 
processual autorizam que o réu (e as demais pessoas vinculadas a ele) minta, já que não está obrigado ao dever de prestar a verdade; enquanto que, em contrapartida, com relação aos fatos construídos pelo Estado, as versões, provas e testemunhos estão corroborados pela noção de veracidade absoluta, inerente aos atos dos agentes que representam o próprio Estado.

Embora o defensor público detenha menor poder de decisão no âmbito processual do que juiz e promotor, uma vez que sua atuação está vinculada à denúncia do Ministério Público e suscetível da sentença do magistrado em momento posterior, há uma relação de micropoder (Foucault, 1999, p. 86) entre ele e o acusado permeada pelo papel institucional e social ocupado por ambos na sociedade.

Se chegarmos em uma sala de audiência e juiz, promotor e defensor público não estiverem sentados em seus lugares cativos dentro daquele espaço, facilmente poderemos confundi-los. Isso porque todos possuem uma aparência próxima, seja pelo tipo de vestimenta, postura ou forma de falar. No caso em questão todos tem a mesma cor de pele, recebem salários aproximados, frequentam os mesmos espaços sociais em momentos de lazer, viajam para os mesmos países. Compartilham assim, capitais simbólicos, sociais e culturais muito similares (Bourdieu, 2007).

O réu, por sua vez, não se confunde com esses atores, mas facilmente se confunde com outros réus. Para além dos estigmas próprios da relação de preso (chinelos, bermudas, camisa e algema), o acusado ocupa um lugar na sociedade muito distinto daquele ocupado por aqueles que conduzem seu processo. A cor de sua pele é à primeira vista a característica mais óbvia. Mas os capitais econômico-social-cultural do acusado fazem transparecer a desigualdade estampada.

Conquanto, sua palavra será recebida em descrédito uma vez que já está condicionada pelo estigma do criminoso, por sua vez atrelado ao estrato social ao qual pertence, já que sua identidade virtual (Goffman, 1985) transparece conceitos e padrões considerados socialmente negativos pelo grupo social ao qual é apresentado. Há uma representação daquilo que é considerado enquanto desvio, posto que caracteriza aqueles que rompem com as regras sociais e colocam em risco a sociedade como um todo. A partir desta máxima, um discurso binário é construído colocando em oposição o outro e o nós. Os réus são estigmatizados porque representam a antítese do que é compreendido por aquele grupo social como a categoria do 
cidadão de bem. Isso ocorre porque a categoria criminoso não é compatível com a categoria normalizada e desejada, o que faz com que o acusado carregue consigo uma incongruência com o estereótipo do cidadão de bem. Isso gera um estigma. Por essa razão a identidade por ele apresentada é descreditada, passível de ser questionada pelos demais atores presentes na audiência e por eles desconsiderada.

Ocorre que, numa sociedade como a brasileira, permeada por grande desigualdade, a categoria conflitos interpessoais encontra forte correlação com o insulto moral (Cardoso de Oliveira, 2010), que é elemento fundamental da violência interpessoal, visto que o componente moral das disputas, muitas vezes, corresponde à percepção do insulto sentida pelo interlocutor. As categorias conflitos interpessoais e insultos morais - protagonizam a questão da afirmação de direitos e das demandas por reconhecimento no cenário jurídico brasileiro. Remontam agressões a direitos que não podem ser adequadamente traduzidos em evidências materiais e implicam uma desvalorização ou negação da identidade do outro. Trata-se de conflitos de caráter habitual, desenvolvidos no cotidiano das sociabilidades e provenientes de algum tipo de interação pretérita entre as partes. São, geralmente, discordâncias que se delongam no tempo, gerador de um histórico de adensamento da divergência. Compartilham de modos de expressão variados na esfera pública e/ou íntima das partes, podendo atingir terceiros não envolvidos na disputa. A notoriedade dessa categoria está ligada, fundamentalmente, a dois aspectos: são conflitos recorrentemente carentes de reconhecimento (Cardoso de Oliveira, 2002) na realidade jurídica e cultural do país e, em contraste, têm desencadeado práticas graves de violência, muitas vezes invisibilidades.

Portanto, é possível afirmar que diante da facilidade de identificar em determinado cidadão substância moral de pessoa digna, as percepções sobre esse indivíduo são delimitadas a partir disto (Cardoso de Oliveira, 2010). Se não é associado ao cidadão o mínimo de dignidade, este indivíduo poderá ser tratado em dissonância aos parâmetros legais que lhe conferem direitos. O insulto moral ocorre nas situações em que a observação dos direitos é acompanhada por certo desprezo ou simplesmente quando aquele que respeita o direito não é capaz de transmitir a convicção de que assim o faz porque reconhece sua dignidade ou a adequação normativa dos direitos àquela circunstância específica (Cardoso de Oliveira, 2002).

Tais circunstâncias são constantemente reiteradas pela atuação da defensoria pública no âmbito criminal. A classificação de indivíduos como "fodidos" e "vagabundos", por exemplo, 
reiteram essa posição que estigmatiza e desiguala indivíduos. Nessa dinâmica os rumos da atuação da defensoria pública são conduzidos pelas moralidades dos próprios defensores públicos que organizam e hierarquizam características e argumentos, numa triagem daqueles casos que são e não são passíveis de defesa, adequando tal dinâmica às características de cada um dos assistidos.

\subsection{A rotina da Defensoria Pública: o procedimentalizar}

Em 2012 eu estava no início da faculdade de Direito e muito empolgada em dar início à aprendizagem do Direito na prática, ou seja, aplicar tudo o que vinha aprendendo através de manuais e doutrinas aos casos concretos que apareceriam. Porém, em muitos momentos, tive tal expectativa frustrada. Eu ainda estava no início dos meus estudos, aprendendo as matérias introdutórias do curso de Direito, muito "crua" para lidar com o cotidiano da defensoria pública com a desenvoltura necessária, como meus demais colegas estagiários, para atender aos assistidos e fazer peças processuais todas as tardes.

Embora o estágio em um órgão pública seja uma fase comum na formação jurídica de estudantes de direito no Brasil, a noção de que a prática está dissociada da teoria não é enunciada nas salas de aula. Isto porque o estudo do direito, tal como reproduzido nas salas de aula do país, é transmitido a partir de construções de natureza dogmática, consubstanciados nos manuais e livros contendo considerações doutrinárias a respeito de determinados assuntos ou mesmo interpretações acerca de leis, sem que seja fidedigno à prática judiciária. A pesquisa científica, quando raramente realizada a respeito do direito, tem objetivo meramente especulativo de conhecimento e sistematização, ou em sentido prático de interpretar as normas jurídicas para sua exata aplicação (Lupetti e Kant de Lima, 2010).

Comecei então a estagiar na defensoria pública. Na estrutura do órgão naquele município, cada defensor era vinculado a um juízo específico, denominado Vara. Nessa dinâmica, a instituição era responsável por prestar a defesa pública a todos os feitos criminais encaminhados ao juízo, quando não houvesse um advogado particular constituído para tanto. 
$\mathrm{Na}$ Vara em que estagiava, além de mim, havia mais um estagiário encarregado do expediente ${ }^{5}$ das audiências preliminares de crimes de menor potencial ofensivo processados pelo Juizado Especial Criminal (Jecrim). Também trabalhava conosco um secretário, que não era graduado em Direito nem prestara concurso público para ocupar o cargo. Não parecia um cargo em confiança, mais se assemelhava a um contrato terceirização. Sua função era organizar e agendar horários de atendimento ao público. Ele também era responsável por realizar uma espécie de triagem, separando os casos que poderiam ser encaminhados ao atendimento principal (pelo defensor ou pelos estagiários) e aqueles cuja documentação era insuficiente ${ }^{6}$.

O atendimento "oficial” era responsabilidade dos estagiários. Eram os responsáveis por orientar e explicar aos assistidos e familiares sobre o andamento do processo. O contato com os defensores era restrito. Embora os estagiários tivessem mais contato com as partes e seus familiares, pouco ou quase nada daquilo por eles narrado chegava de fato ao defensor ou era assimilado por este.

O defensor público titular da Vara passava a maior parte do tempo do seu trabalho em audiências, que levavam muitas vezes o dia inteiro acontecendo. A ausência dos defensores nas Varas em que trabalham motivada pela necessidade da sua presença em audiências nos mesmos horários do atendimento ao público era comum a praticamente todas as Varas.

Essa agenda estreita, que deveria estar em compasso com a do juiz titular da Vara correspondente no Tribunal, bem como com a do promotor de justiça, ainda dava azo para o defensor - de maneira semelhante aos outros colegas de profissão - ter acesso aos processos e conhecer os réus ou seus familiares apenas no momento das audiências. Porém, destas eu não possuía permissão para participar, porque os estagiários tinham bastante a desempenhar na defensoria, afinal, alguém precisava atender aos assistidos.

\footnotetext{
${ }^{5}$ Expediente é uma categoria usada para todos os atos realizados no âmbito do processo judicial. O expediente é diário, são enviados à defensoria autos processuais com prazos em aberto para ciência por parte do defensor ou para confecção de peças processuais próprias da defesa.

${ }^{6}$ Era comum que assistidos e seus familiares comparecessem à defensoria com documentos ilegíveis ou inconsistentes. Ele os encaminhava a órgãos oficiais, formalmente (através da expedição de ofícios) ou informalmente (simplesmente lhes dando o endereço de onde deveriam se dirigir).
} 
Uma das primeiras coisas que aprendi foi a fazer o modelão de Resposta à Acusação ${ }^{7}$. Era simplesmente uma peça processual salva nos arquivos do computador que era usado pelos estagiários da Vara, com dizeres básicos, sem muita profundidade jurídica ou argumentativa, apenas a defesa técnica em poucas palavras. Era assim, então, que a primeira possibilidade do réu se manifestar nos autos do processo acontecia. Bastava mudar o nome do réu, o número do processo, colocar ou tirar nomes e dados (telefone e endereço) das pretensas testemunhas (porque todas poderiam mudar na audiência) e modificar a data ao final da folha. Caso a parte ré estivesse ali (respondendo ao processo em liberdade), ela iria assinar ao final da folha a Resposta à Acusação. Embora o contato com os réus e seus familiares tivesse por objetivo a confecção das respectivas Respostas à Acusação, as entrevistas com os réus presos raramente eram utilizadas para a escrita desta peça processual, sendo mais uma maneira de tornar procedimento a garantia constitucional do acusado. Esse mesmo cenário de "copiar e colar" nas telas dos computadores textos de defesa se dava para as demais peças, inclusive Alegações Finais, com exceção das que o defensor separava para que ele mesmo fizesse, as dos casos que ele entendia como "mais difíceis".

A atividade era automática e padrão. A ideia de um modelão que não necessariamente está vinculado ao caso concreto, remete à produção da norma no Brasil: fatos precisam se enquadrar às normas, numa expressão de ser/dever ser e não de um se/então (Geertz, 1998, p. 249). Nessa dinâmica, as particularidades dos casos concretos são ignoradas e dão lugar à uma linha de produção. A manifestação da defesa passa a ter um papel meramente formal, assim como outros atos praticados dentro do processo e também nas audiências, que são levados a termo só por formalidade (Eilbaum, 2012). A atividade fim é procedimentalizar um ato processual sem compromisso com a confecção de um documento de defesa efetiva do acusado no caso concreto. A ideia de enxugar gelo muito difundida nos órgãos públicos explica bem essa dinâmica. As atividades dos atores que participam das etapas defensivas do processo são limitadas ao cumprimento de um mero ato oriundo do fluxo processual.

\footnotetext{
${ }^{7}$ A resposta à acusação está prevista no artigo 396 do Código de Processo Penal Brasileiro: "Nos procedimentos ordinário e sumário, oferecida a denúncia ou queixa, o juiz, se não a rejeitar liminarmente, recebê-la-á e ordenará a citação do acusado para responder à acusação, por escrito, no prazo de 10 (dez) dias”. Em seguida, o artigo 396A do mesmo diploma legal diz que: "Na resposta, o acusado poderá arguir preliminares e alegar tudo o que interesse à sua defesa, oferecer documentos e justificações, especificar as provas pretendidas e arrolar testemunhas, qualificando-as e requerendo sua intimação, quando necessário.”
} 
Este é um pequeno demonstrativo de como os estagiários da defensoria pública, desta maneira, desempenhavam atuação central na lida com os assistidos e com suas demandas, atendendo tanto aos réus como aos seus familiares, fazendo peças processuais (mesmo que com base nos modelões na maioria das vezes, que apenas aguardavam a breve correção pelo defensor e sua assinatura para protocolar), atuando tal qual advogados nos balcões dos cartórios e orientando acordos no Jecrim, graças ao enorme imperativo que o processo tem de fazer com que todos os atos em função dele, impregnados das moralidades das pessoas neles envolvidas, façam parte de seu procedimento, sem muito importar seus resultados.

\section{ASSISTIR OU TUTELAR?}

O defensor saiu no corredor. Os autos do processo nas mãos. Leu o nome do acusado em voz alta e perguntou pela família. A mãe estava ansiosa, queria saber o resultado da audiência. Ele ia sair em poucos dias. "A juiza deferiu a liberdade provisória”. Era um caso de furto sem violência, praticado em concurso de agentes. O jovem de 19 anos não tinha antecedentes penais e, para sua "sorte" o coautor assumira toda responsabilidade pelo crime. A mulher de meia idade pareceu confusa: “isso quer dizer que ele vai pra casa?”. O defensor explicou que dentro de alguns dias ele seria libertado. "Vão expedir o alvará de soltura". A mãe estava aliviada e muito agradecida.

$\mathrm{O}$ diálogo não terminou na verbalização do sentimento de gratidão da mulher. $\mathrm{O}$ defensor queria alertá-la. "Seu filho anda com umas companhias complicadas". A frase anunciou um discurso sobre a importância daquela mãe vigiar, instruir e orientar o filho para que ele não voltasse àquela condição. Ele não acreditava na inocência do jovem. " $O$ colega assumiu a culpa pra ele não ficar com a ficha suja". Ainda assim reiterou para a mãe que acreditava que ele seria absolvido pelo juízo. "Mas se ele voltar aqui, não vai ter uma segunda chance, você precisa manter ele na linha”.

Uma defensora me contou que os casos despertavam sentimentos nela. "Eu não quero julgar, mas...". Sempre repetia que as mães dos acusados eram aquelas que mais sofriam ao longo do processo. Ela costumava dizer que a pena era pior para elas do que para os condenados. 
Ela também é mãe e não conseguia imaginar criar os dois filhos que ainda eram crianças sem participar da rotina deles. Ela dizia conversar com os meninos sobretudo. Fazia questão de leválos na escola e estar em casa antes do pai buscá-los na natação. "Não quero ser dessas mães que não sabe onde os filhos estão e com quem estão". Ela dizia que até entendia que a situação econômica podia dificultar a relação com os filhos, mas que não conseguia entender como uma mãe poderia criar um filho "largado no mundo".

Outro defensor, interlocutor frequente, atribuía o local de residência dos criminosos como o fator mais relevante e (quase) predeterminante para o cometimento do delito. Segundo ele os espaços favela, bairros pobres produzem tendências criminosas, já que para ele, a personalidade individual é formada tendo como base os cenários e atividades cotidianas compartilhadas pelos sujeitos que vivem em determinado local.

A relação dos jurisdicionados com a justiça e seus operadores, nos remete ao texto de Pedro Heitor de Barros Geraldo (2013). Sua pesquisa versou sobre as audiências e os juízes de proximidade na França, propondo uma análise do encontro entre juristas e jurisdicionados. $\mathrm{O}$ autor entendeu a audiência como objeto de pesquisa pouco comum, mas útil para compreender as práticas dos profissionais do direito. Sua observação centrou-se no questionamento da retórica e formalidade como base do trabalho do direito. Levantou questões, também, sobre um entendimento comum no qual o papel dos juristas seria reconhecer o direito e explicitá-lo de forma elegante e convincente.

As audiências estudadas pelo autor se diferenciam muito das audiências conduzidas no campo em questão e no país, como um todo. Apesar das características similares aos dois sistemas de justiça que são oriundos da Civil Law, no tribunal francês vários processos são instruídos e julgados ao longo de uma sessão de audiências, enquanto no Brasil cada audiência corresponde a um processo. O efeito dessa prática, no caso francês, é a criação de um ritual pedagógico já que os jurisdicionados, vendo os outros processos serem julgados, são informados sobre a maneira de agir na audiência do seu próprio processo e também sobre questões e fundamentos legais como um todo.

No Brasil, raramente há essa plateia. Os réus chegam ao fórum; quando soltos, aguardam nos corredores e quando presos na carceragem. Estão presentes apenas em suas audiências e depois se vão. Isso foi explicado pela característica opaca e empírica da nossa 
sensibilidade jurídica, como explicita Kant de Lima (2013). Soma-se a isso o fato de que no Brasil o público não é algo que pertence a toda sociedade, mas ao Estado (Kant de Lima, 1999, p. 24), que por sua vez é composto por atores que representam um extrato social distinto da maior parte dos jurisdicionados, sobretudo no âmbito penal. Lenin Pires (2006), explica que não é possível verificar na aplicação da lei no espaço público contornos democráticos, uma vez que as normas não seriam válidas para todos de maneira igual. Diante dessa situação, "o espaço público é submetido a regras gerais, e não locais. É lugar apropriado de forma particular, seja pelo Estado ou por membros da sociedade autorizados ou não por ele”.

Dessa forma, a comunicação com os réus e seus respectivos familiares fica a cargo da defesa, já que a contato com o jurisdicionado é de incumbência desses atores. Por isso a rotina se repete com frequência nos corredores dos fóruns. Defensores vez e outra saem das salas de audiência e chamam em alta voz pelos parentes do acusado, informam a eles se o Réu já está no fórum, perguntam se os familiares têm provas documentais ou testemunhais a serem apresentadas na audiência. Aquele costuma ser o primeiro contato com os familiares. Não destes com a instituição defensoria, mas com o defensor.

A mesma dinâmica se repete em relação ao acusado e eventuais testemunhas de defesa. Há uma preocupação em explicar o ritual judicial e instruir sobre o comportamento esperado. É evidente o movimento da defesa no sentido de traduzir a linguagem jurídica para uma que seja mais inteligível aos assistidos, explicando detalhes opacos e pouco palpáveis para aqueles que não compartilham a desta linguagem, embora nem sempre seja algo simples. Certa vez um defensor explicou que era cansativo orientar esses atores já que muitas vezes a "tradução" era ineficiente. Era necessário reconstruir frases e reinterpretar sentidos da linguagem jurídica "é tão inerente à nossa atuação e a linguagem deles é tão distante...”.

Mais uma vez o nós e o outro aparece nos discursos e nas práticas dos atores. Atuar na defesa de processos criminais, nesse contexto, é mais do que manipular o processo penal. A atuação envolve uma assistência para além do ritual, que está orientada pelas próprias moralidades dos defensores públicos. Nesse exercício o papel de assistente social, auxiliar à instituição, muitas vezes é assumido pelo defensor, resultante numa relação de tutela. Não se trata aqui de uma tutela de direitos, atinente à atuação da própria instituição, que visa a consolidação de direitos fundamentais e a promoção da cidadania. A tutela nesse caso ganha uma conotação binária, orientada pelas noções de bem e mal, certo e errado, normal e anormal 
presente nas representações dos próprios defensores sobre a estrutura e a dinâmica da sociedade, bem como do olhar sobre o outro.

\section{CONSIDERAÇÕES FINAIS}

As práticas e discursos dos defensores públicos revelam uma tendência à "procedimentalização" das atividades cotidianas. De modo que, as relações com os "assistidos" e seus respectivos familiares, além de despontarem numa tendência de tutelar essas partes a partir de suas próprias moralidades, também revelam um certo conformismo com relação ao julgamento das sentenças. A tutela nesse caso ganha uma conotação binária, orientada pelas noções de bem e mal, certo e errado, normal e anormal presentes nas representações dos próprios defensores sobre a estrutura e a dinâmica da sociedade, bem como do olhar sobre o outro.

Não há por parte do defensor público nenhum movimento no sentido de buscar a produção de provas defensivas especificamente relacionadas aos fatos. A atividade da defesa muitas vezes se limita à mitigação da pena, a partir da apresentação das condições subjetivas dos réus: se têm família, dependentes econômicos, antecedentes penais, vínculo profissional e etc.

As práticas institucionais são em sua maioria desempenhadas por profissionais que estão vinculados ao serviço público em condição temporária, já que não são servidores públicos aprovados em concursos, mas contratados em regime provisório. O contato com as partes é feito eminentemente por esses profissionais. O defensor público, não raramente, só tem contato com as partes no dia da audiência.

Chamam atenção, de igual modo, os discursos que circulam na instituição com relação à pessoa do assistido, muitas vezes categorizados enquanto "vagabundas" e/ou "fodidos". Tais práticas e discursos estão diretamente relacionados com a posição que o defensor ocupa na sociedade brasileira proporcionalmente desigual aquela ocupada pelo assistido. $\mathrm{O}$ pertencimento à instituição defensoria, que não é compreendido como um serviço público no 
sentido de algo que pertence e é oferecido à toda sociedade, senão como uma instituição pertencente ao Estado, que a partir de suas práticas, reitera uma posição hierárquica e desigual. Nesse cenário, aqueles que exercem uma atividade profissional vinculada ao Estado se desigualam da sociedade e consequentemente daqueles que recorrem ao serviço público. Diante desse cenário de desigualdades e hierarquia, a prestação desse serviço público é desempenhada também de forma desigual e hierárquica, na qual as moralidades da defesa servem de norte para sua atuação.

\section{REFERÊNCIAS BIBLIOGRÁFICAS}

BECKER, Howard S. (1993), Problemas de interferência e prova na observação participante. In: Métodos de pesquisa em ciências sociais. São Paulo: Editora Hucitec.

BOURDIEU, Pierre. A economia das trocas simbólicas. São Paulo, 2007.

, Pierre. O poder simbólico. 6 ed. Rio de Janeiro: Bertrand Brasil, 2003.

CARDOSO, Adalberto. A construção da sociedade do trabalho no Brasil: uma investigação sobre a persistência secular das desigualdades. $2^{\text {a }}$ Edição. Amazon. Rio de Janeiro, 2019.

EILBAUM, Lucía. Só por formalidade: A interação entre os saberes antropológico, jurídico e judicial em um juicio penal, 2012. Porto Alegre: Horizontes Antropológicos.

EILBAUM, Lucía. Quando o Peixe morre pela boca: Os casos de Polícia na Justiça Federal argentina na cidade de Buenos Aires, 2006. Dissertação de Mestrado apresentada ao Programa de Pós-Graduação em Antropologia da Universidade Federal Fluminense.

FOUCAULT, Michel. A verdade e as formas jurídicas, 1999. Rio de Janeiro: Nau.

GARAU, M. G. R.; LUZ, V. C. Educação em direitos: sentidos e práticas a partir do contraste e do diálogo entre entre as experiências das defensorias públicas e da assessoria jurídica popular. In: Defensoria Pública, Assessoria Jurídica Popular e Movimentos Sociais Populares: novos caminhos traçados na concretização do Direito de Acesso à Justiça. 1ed.Goiás: ANADEP, 2017, v. 2, p. 219-250.

GEERTZ, Clifford. $O$ saber local: fatos e leis em uma perspectiva comparativa. Petrópolis. Vozes, 1998. FGV.

GERALDO, Pedro Heitor. Entre as leis e as normas: éticas corporativas e práticas profissionais na segurança pública e na Justiça Criminal. DILEMAS: Revista de Estudos de Conflito e Controle Social. Rio de Janeiro: Núcleo de Estudos da Cidadania, Conflito e Violência Urbana (Necvu). v. 6, n. 4, p. 549-580, out./nov./dez. 2013. Disponível em: 
<http://revistadil.dominiotemporario.com/doc/DILEMAS-6-4-Art1.pdf>. Acesso em: 10 out. 2015.

GOFFMAN, Erving. Estigma: Notas Sobre a Manipulação da Identidade Deteriorada. 4 ed. Rio de Janeiro: Livros Técnicos e Científicos, 1985.

KANT DE LIMA, Roberto. Polícia, justiça e Sociedade no Brasil: uma abordagem comparativa dos modelos de administração de conflitos no espaço público. REVISTA DE SOCIOLOGIA E POLÍTICA No 13: 23-38 NOV. 1999.

KANT DE LIMA, Roberto; EILBAUM, Lúcia; PIRES, Lenin (orgs). Conflitos, Direitos, $e$ Moralidades em perspectiva comparada, 2010. Rio de Janeiro, Garamond.

MALINOWSKI, Bronislaw. Argonautas do Pacífico Ocidental: um relato do empreendimento e da aventura dos nativos nos arquipélagos de Nova Guiné melanésia. Traduções de Anton P. Carr e Lígia Aparecida Cardieri Mendonça; revisão de Eunice Ribeiro Durham. 2a edição. São Paulo: Abril S.A. Cultural e Industrial, 1978.

NUÑEZ, Izabel Saenger. Aqui não é casa de vingança, é casa de Justiça!: moralidade, hierarquizações e desigualdades na administração de conflitos no tribunal do júri da comarca do Rio de Janeiro. Niterói: Universidade Federal Fluminense, 2018. 283p. Tese (Doutorado) Universidade Federal Fluminense. Pós-graduação em Antropologia.

OLIVEIRA, Luís Roberto Cardoso de. A dimensão simbólica dos direitos e a análise de conflitos. Revista de Antropologia da USP, Departamento de Antropologia da Faculdade de Filosofia, Letras e Ciências Humanas da Universidade de São Paulo - vol. 53(2), julhodezembro 2010, São Paulo, SP.

Direito Legal e Insulto Moral. Rio de Janeiro: Relume Dumará, 2002.

PIRES, Lenin. "Deus ajuda a quem cedo madruga?": trabalho, informalidade e direitos civis nos trens da Central do Brasil. In: GROSSI, Miriam Pillar (Org.). Antropologia e Direitos Humanos, vol. 4. Blumenau: Nova Letra, 2006.

Data de Submissão: 16/04/2020

Data de Aceite: 02/02/2021 